\title{
Changes in Temperature and Precipitation with the Analysis of Geomorphic Basin Chaos in Shiraz, Iran
}

\author{
Shahide Dehghan ${ }^{1}$, Sayed Abdol Ali Kamaneh², Saeid Eslamian ${ }^{3}$, Amir Gandomkar ${ }^{4}$, \\ Maryam Marani-Barzani ${ }^{5}$, Mahboubeh Amoushahi-Khouzani ${ }^{6}$, Vijay P. Singh ${ }^{7}$, \\ Kaveh Ostad-Ali-Askari ${ }^{*}$ \\ ${ }^{1}$ Department of Geography, Najafabad Branch, Islamic Azad University, Najafabad, Iran \\ ${ }^{2}$ Department of Geography, Shiraz Branch, Islamic Azad University, Shiraz, Iran \\ ${ }^{3}$ Department of Water Engineering, Isfahan University of Technology (IUT), Iran \\ ${ }^{4}$ Department of Geography, Najafabad Branch, Islamic Azad University, Najafabad, Iran \\ ${ }^{5}$ Department of Geography, University of Malaya (UM) ,50603 Kuala Lumpur, Malaysia. \\ ${ }^{6}$ Water Engineering Department, Science and Research Branch, Islamic Azad University, Tehran, Iran \\ ${ }^{7}$ Department of Biological and Agricultural Engineering \& Zachry Department of Civil Engineering, \\ Texas A and M University, 321 Scoates Hall, 2117 TAMU, College Station,U.S.A. \\ ${ }^{8 *}$ Department of Civil Engineering, Isfahan (Khorasgan) Branch, Islamic Azad University, Iran
}

\section{*Corresponding author:}

Kaveh Ostad-Ali-Askari., Department of Civil Engineering, Isfahan (Khorasgan) Branch, Islamic Azad University, University Blvd, Arqavanieh, Jey Street, Isfahan, Iran,

Email: Koa.askari@khuisf.ac.ir

\begin{abstract}
Applying the logic of chaos in understanding many details of natural phenomena is unexplainable. At this paper, the climate changes of temperature and precipitation over the analysis of chaos in Shiraz geomorphic basin will be discussed. Climate changes of a long-term temperature and precipitation were used for 40 years. Then, geomorphic basin physiognomic characteristics were examined at the most superficial layer and the climatic elements were analyzed. The results of this study suggest that climate change of Shirazbasin geomorphic structure is a function of non-linear algebraic curves.
\end{abstract}

Keywords: Shiraz basin geomorphic, chaos, climate change, temperature, precipitation.

\section{INTRODUCTION}

Chaos is a concept that expresses some kind of order in the chaotic process framework. Although it is more a similar fallacy from a philosophical point of view, but shortly after stating the theory it was expanded. The studies of Jones et al. (1986) and Hansen and Lebedev (1987) were the most important researches in this field that various components of last century's temperature were considered according to these characteristics.

Precipitation is one the important climate factor. Today, the issue of climate change increases the temperature, precipitation, floods, droughts, heat waves, melting polar ice, changes in rainfall time and space, disrupting the hydrological balance, and management strategies; because the water resource managers and researchers didn't expect such a severe impact on the climate and hydrology parameters. In the last few decades, Chaos theory is the basis of nonlinear dynamical systems, which has created a great development in the way of understanding and expression of phenomena. This theory examines such a system that at first glance may seem random, but in fact are governed by specific laws. Such systems are called chaotic.

The purpose of this paper is to study the climate changes on geomorphic basin of Shiraz during the last fifty years. It should be noted that the process of climate change and climate variability of Shiraz basin are completely independent of each other. 


\section{MATERIAL \&MethodS}

Shiraz geomorphic basin an area of 3931.84 square kilometers, which is located at the 52 degrees 13 minutes and 16 seconds to 53 degrees 28 minutes 59 seconds east longitude and 29 degrees 15 minutes' north latitude and 29 degrees 55 minutes 59 seconds. In choosing the method of determining the climate of Shiraz basin algorithm, a combined method must be used as follows:

A. At early researches, the climate data will be extracted from the National Weather Service by using the library methods. Given that the climate data extracted from synoptic stations in the surrounding area of Shiraz cityin Fars province were settled in the political sphere, that's why the statistics for thirty years at all stations in the surrounding area of Shiraz basin are collected.

B. The information is gathered digitally from the field observations of geomorphological information on Gps to a geographic information system. Using the topographic maps of 1: 50,000 and 1: 250,000 , the height and slope of Shiraz geomorphic basin become digital.

C. Then, according to Pythagorean algebraic golden ratio), the climatic characteristics have been analyzed. It should be noted that during the estimation, it isn't necessary to insert exactly the golden ratio changes and climate fluctuations. But what is important is the ratio between output systems. This is because, like the natural logarithm of the ratio or Radian constant, it is an irrational number and acyclic return.

\subsection{Problem Statement}

The full climatological practices and behaviors are analyzed based on the climate changes and fluctuations. Shiraz geomorphic basin is very important as one of the major poles of population, industry, and agriculture. In other words, agriculture, industry, economy, human development and natural resources in the province, especially Shiraz, are dependent on the weather and hence, volatility and changes play the significant role during the short-term, medium-term and long-term in sustainable development of Shiraz. Because Shiraz geomorphic basin is considered as one of the exceptional and unique Zagros geomorphological Basin, the evaluation of climate changes on Shiraz geomorphic basin in cooperation with independent geomorphic basins is ended to a height of 1550 meters above sea level on Bakhtegan Lake. Human beings, both living and non living, have no control over the developments of dynamic and thermodynamic climates. Although emphasizing on this fact is also quite logical that human activities can cause these changes in the macro-scale, medium and micro affect, but it governs the matter from the physical identity point of view.

\subsection{The Temperature Zoning of Shiraz Geomorphic Basin}

Having knowledge about the distribution of temperature programming is considered necessary at natural and agricultural sources. According to the spatial distribution of these characteristics in this study geostatistical methods in the study of zoning and spatial distribution of temperature properties were evaluated in Fars province .

The results showed that the evaluated spatial characteristics have followed the Gaussian and spherical models. Among the methods used to estimate, the weighting method was the best way to inverse distance. Northern parts of the province have the lower average long-term temperatures than the southern part, while other parts of central and southern areas, especially west of the province, have more than average temperatures and sunshine hours. Given that geomorphic basin is located in Shiraz, so in order to obtain a more comprehensive conclusion the zoning of Province would have to be taken. As you can see, the North-East province is governed by a traffic temperatures of $17^{\circ} \mathrm{C}$. on the above map, the location of Shiraz is determined; so, we have to inevitably overlap GIS map of Shiraz basin and then cut it to receive the status of Shiraz basin's temperature. Thermal cutting of Shiraz basin is shown in Figure (1-1). 


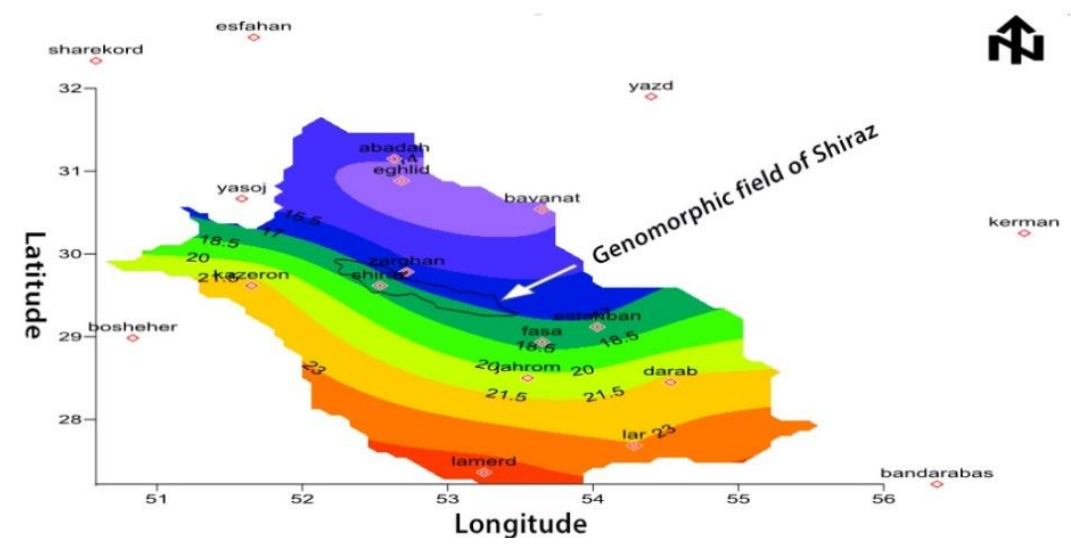

Figure1. Average long-term mean annual temperature of Fars

At this data zoning, the area has not been affected by the traffic of thermic. The province in the NorthEast region is faced with a much traffic the outside traffic intersection is located in Yazd province. So, neither the province nor the Shiraz geomorphic basin traffic is not formed. It should be noted that this is ruled on Shiraz geomorphic basin, while it is also located in the southeastern part of Shiraz geomorphic basin to completely change the heating lines and reverse them.

\subsection{Temperature Changes of Shiraz Geomorphic Basin}

Temperature is one of the most important factors of Shiraz geomorphic basin. So, we check the status of temperature changes for thirty years in the form of tables (1-1).

A simple mathematical analysis can be used to form a series of temperature changes at Shiraz basin. Figure (1-1) display the changes in temperature of Shiraz station. As the Figure (1-1) shows, the thirty-year radiation and temperature changes are experiencing a chaos. This chaos is visible on the graph, but its process must be analyzed. Another way of understanding the appearance of chaos in ascending charting is the process of temperature changes.

\begin{tabular}{|c|c|c|c|c|c|c|c|c|c|c|c|c|c|c|c|c|c|c|}
\hline \multirow[t]{2}{*}{ Long-term } & \multicolumn{7}{|c|}{ Average long-term temperature } & \multicolumn{3}{|c|}{$\begin{array}{l}\text { Relative } \\
\text { monthly } \\
\text { humidity }\end{array}$} & \multicolumn{3}{|c|}{ Rainfall(Millimeter) } & \multirow{2}{*}{\begin{tabular}{|c|} 
Evaporation \\
\\
\end{tabular}} & \multirow{2}{*}{\begin{tabular}{|r|} 
Sunshine \\
\\
\end{tabular}} & \multirow{2}{*}{\begin{tabular}{|c|}
$\begin{array}{c}\text { Day } \\
\text { Number }\end{array}$ \\
\\
\\
$\mathbb{7}$ \\
$\overrightarrow{0}$ \\
$\stackrel{0}{\gtrless}$ \\
\end{tabular}} & \multicolumn{2}{|c|}{$\begin{array}{l}\text { Max } \\
\text { wind }\end{array}$} \\
\hline & 当 & 竝 & 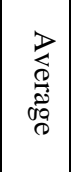 & $\underset{\otimes}{\stackrel{\Xi}{<}}$ & 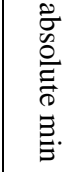 & $\underset{\otimes}{\stackrel{\otimes}{<}}$ & 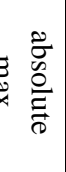 & 水 & 3 & 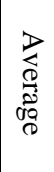 & $\begin{array}{l}\stackrel{\Xi}{\Xi} \\
\stackrel{\Xi}{\Xi}\end{array}$ & 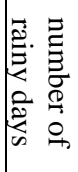 & 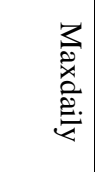 & & & & 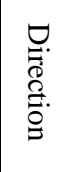 & 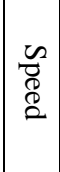 \\
\hline Farvardin & 8.0 & 22.1 & 15.1 & 8 & -1.4 & 25 & 31.2 & 25 & 71 & 48 & 39.6 & 8 & 74.2 & 5.0 & 8.5 & 0 & 257 & 15 \\
\hline Ordibehesht & 13.0 & 29.1 & 21.0 & 7 & 3.6 & 28 & 37.8 & 17 & 56 & 37 & 13.5 & 4 & 44.2 & 7.8 & 9.9 & 0 & 256 & 15 \\
\hline Khordad & 17.2 & 35.0 & 26.1 & 8 & 8.0 & 25 & 40.6 & 11 & 38 & 25 & 0.5 & 0 & 5.8 & 10.6 & 11.8 & 0 & 274 & 13 \\
\hline Tir & 20.6 & 38.1 & 29.4 & 11 & 13.0 & 19 & 43.2 & 11 & 37 & 24 & 0.6 & 1 & 15.6 & 11.2 & 1.3 & 0 & 221 & 12 \\
\hline Mordad & 20.6 & 27.7 & 29.2 & 20 & 12.4 & 14 & 42.0 & 12 & 41 & 26 & 1.4 & 1 & 22.6 & 10.4 & 11.0 & 0 & 251 & 13 \\
\hline Shahrivar & 16.9 & 35.1 & 26.0 & 25 & 8.3 & 6 & 39.6 & 12 & 43 & 27 & 0.1 & 0 & 2.2 & 9.0 & 10.7 & 0 & 242 & 12 \\
\hline Mehr & \begin{tabular}{|l|}
11.7 \\
\end{tabular} & 29.7 & 20.7 & 25 & 3.0 & 6 & 36.2 & 14 & 51 & 32 & 1.7 & 1 & 25.5 & 6.6 & 9. & 0 & 276 & 12 \\
\hline Aban & 6.4 & 22.7 & 14.5 & 25 & -5.0 & 5 & 29.4 & 22 & 66 & 44 & 19.7 & 3 & 56.9 & 4.2 & 8.1 & 1 & 262 & 12 \\
\hline Azar & 2.4 & 16.1 & 9.3 & 19 & -6.4 & 6 & 24.4 & 33 & 77 & 55 & 65.9 & 6 & 100.4 & 2.5 & 6.8 & 7 & 249 & 12 \\
\hline Dey & 0.7 & 12.5 & 6.6 & 19 & $\begin{array}{c}- \\
14.4\end{array}$ & 13 & 22.4 & 39 & 83 & 61 & 82.8 & 9 & 221.0 & 2.5 & 6.7 & 15 & 243 & 11 \\
\hline Bahman & 1.1 & 13.4 & 7.3 & 11 & -9.6 & 21 & 23.5 & 34 & 80 & 57 & 60.7 & 9 & 59.3 & 2.9 & 7.3 & 13 & 241 & 13 \\
\hline Esfand & 4.4 & 17.4 & 10.9 & 8 & -6.8 & 19 & 27.4 & 28 & 75 & 51 & 52.2 & 9 & 39.2 & 4.0 & 7.7 & 3 & 241 & 14 \\
\hline Sum & & & & & & & & & & & 338.7 & 51 & & 76.5 & 109.5 & 39 & & \\
\hline Avrg & \begin{tabular}{|l|}
10.3 \\
\end{tabular} & 25.8 & 18.0 & & 0.4 & & 33.1 & 21 & 60 & 41 & & 4 & & 6.4 & 9.1 & 3 & 251 & 13 \\
\hline Min & & & & & $\begin{array}{c}- \\
14.4 \\
\end{array}$ & & & & & & & & & & & & & \\
\hline Max & & & & & & & 43.2 & & & & & & 221.0 & & & & & \\
\hline
\end{tabular}

Table1. Thirty Years Climatic Factors of Synoptic Station in Shiraz. Source of Geological Survey

To draw these charts, data in Table (1-1) were used. So that all temperatures are then normally arranged in ascending order and line graph will be drawn. In the expression of figure (1-1) must be mentioned that if the temperature changes have a static mode, the pulses must be completely in the same process. 


\subsection{The Annual Temperature Changes of Shiraz Geomorphic Basin}

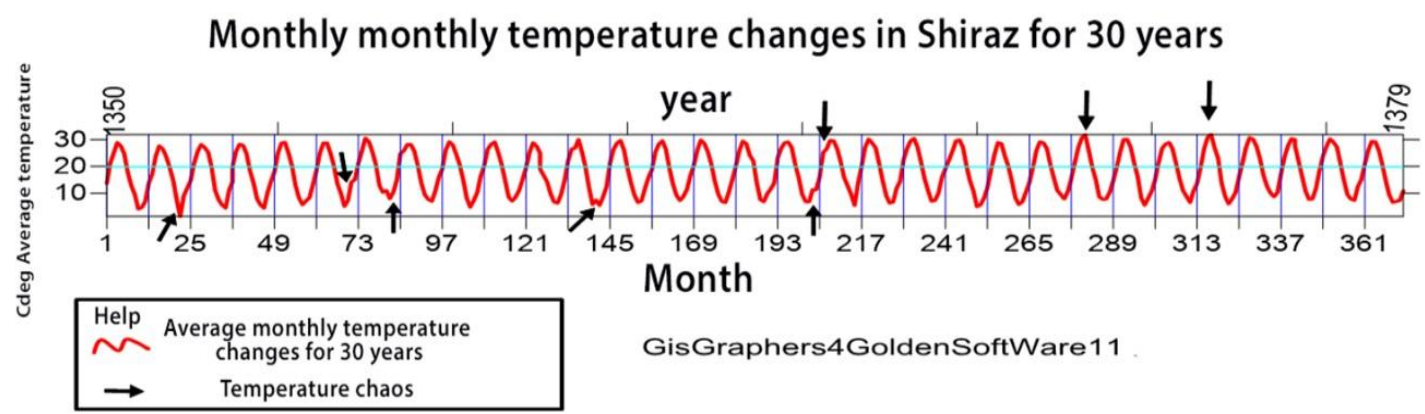

Figure2. Changes in annual temperature of the geomorphic basin of Shiraz

In Figure (2-1), the average monthly temperatures have been set in ascending order for Shiraz and then are plotted with the forms of line graph. As the Figure shows that in some parts, the slope failure is significant.

According to the above quantity and the positive trend of 95 percent at long-term average monthly temperature, the thermal imbalance of geomorphic Shiraz is calculated as follows:

$T=\left(e^{0.991}\right) M^{0.538}$

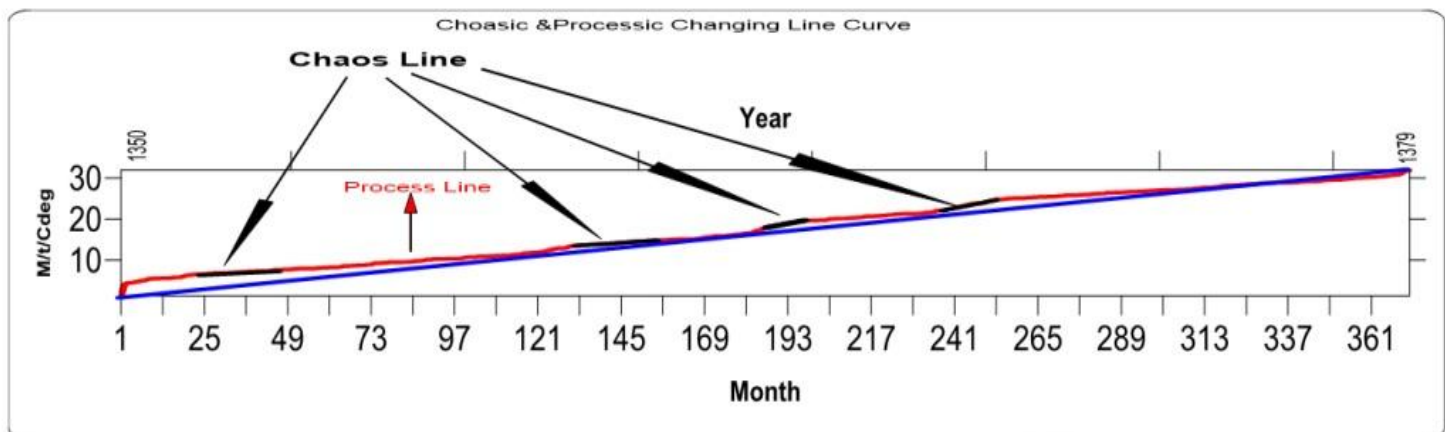

Figure3. Chart of Trend Linear Changes in the Monthly Temperatures of the Geomorphic Basin of Shiraz for Thirty Years

With this calculation and very minor differences, for example, the lowest average temperatures in January are not relevant. It is absolutely clear that first up to thirty row temperatures are belonged to January, because the lowest levels are applied to them. To calculate the area of the Kayes temperature of Shiraz geomorphic, we calculate the value of $\mathrm{M}$ to the function $\mathrm{T}$ :

$M=\left(e^{\left.\frac{\ln \left(\frac{t}{2.716}\right)}{0.538}\right)}\right.$

\subsection{The Zoning of Precipitation at Shiraz Geomorphic Basin}

Having knowledge about the distribution of temperature programming is considered necessary at natural and agricultural sources. According to the spatial distribution of these characteristics in this study geostatistical methods in the study of zoning and spatial distribution of temperature properties were evaluated in Fars province. With a mean of rainfall data in January, February and March, the seasonal rainfall time series for each station is calculated and then normalized correlation matrix was created between data. In the next stage, the eigenvalues, time series of main components and loading factors were also assessed. The first and second components, which were explained collectively as $68 / 1 \%$ of the total variance, were considered as the principal component and also used for zoning rainfall. 


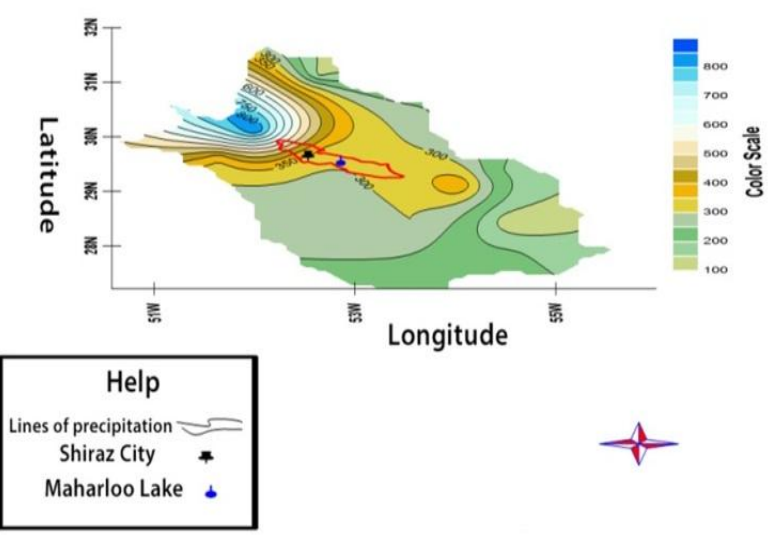

Figure4.Characteristics of the Chisonic Structure of Changes in Precipitation in the Shiraz Geomorphic Basin in Voxler3 Software

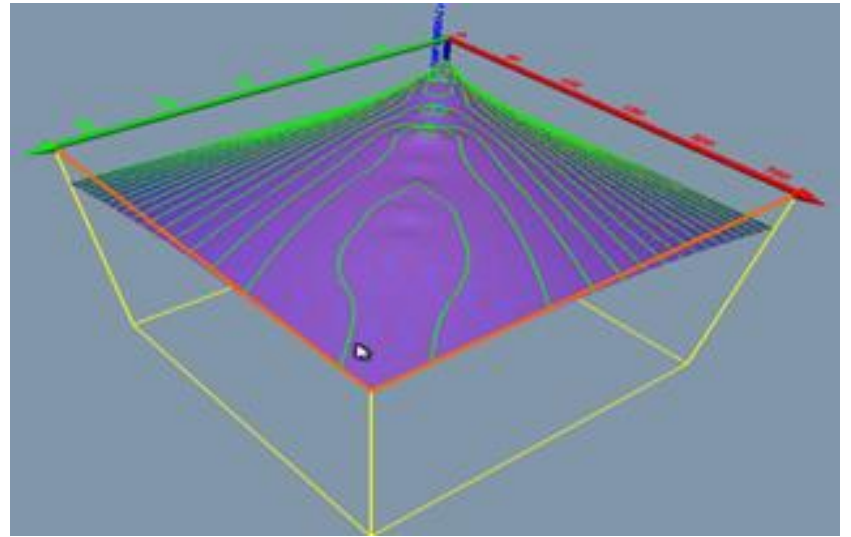

Figure5. Surface zonation of geomorphic basin of Shiraz compared to other areas of the province

Vectors corresponding to the second principal loading component showed large amounts for Bavanat in Northern Province. This area was considered as independent regions corresponding to the second component.

\section{ReSUlts}

Shiraz geomorphic basin is very important as one of the major poles of population, industry, and agriculture. In other words, agriculture, industry, economy, human development and natural resources in the province, especially Shiraz, are dependent on the weather and hence, volatility and changes play the significant role during the short-term, medium-term and long-term in sustainable development of Shiraz. It is necessary to require that Shiraz geomorphic basin like any natural basin at ground level is a dynamic basin. The results showed that the evaluated spatial characteristics have followed the Gaussian and spherical models. Among the methods used to estimate, the weighting method was the best way to inverse distance. Northern parts of the province have the lower average long-term temperatures than the southern part, while other parts of central and southern areas, especially west of the province, have more than average temperatures and sunshine hours. The occurrence of some natural elements, especially climatic parameters, is defined outside the functions. As an example, the structures like

$\Gamma(\mathrm{k})=\int_{0}^{\infty} y^{k-1} * \exp (-y) d y$

And

$Y=\int_{-\infty}^{\infty} .39894228 \exp { }^{\left(-\frac{x^{2}}{2}\right) d x}$

Shouldn't be used in predictions, because fluctuations and changes express the chaos structure $Y=$ $m X^{n}$. 
At this structure,

$Y=\left(1 / \int_{\alpha}^{\beta}\left(\left(m X^{n}\right) d x\right) * \int_{\mathrm{A}}^{\mathrm{B}}\left(\left(\left(m X^{n}\right) d x\right) d x\right) * 100\right.$

Is used to calculate the probability of each parameter.

As a result, the return period of

$\mathrm{T}=\left(1 /\left(\left(1 / \int_{\alpha}^{\beta}\left(\left(m X^{n}\right) d x\right)\right) *\left(\int_{\mathrm{A}}^{\mathrm{B}}\left(\left(m X^{n}\right) d x\right)\right)\right)\right)^{-1}$

Is used to calculate the return period with the domain $1 \leq \mathrm{X} \leq\left(1{ }^{*} 10^{\wedge} 9\right) \mathrm{XI}$.

$L N(\mathrm{~T})=-L N\left(1 /\left(\left(1 / \int_{\alpha}^{\beta}\left(\left(m X^{n}\right) d x\right)\right) *\left(\int_{\mathrm{A}}^{\mathrm{B}}\left(\left(m X^{n}\right) d x\right)\right)\right)\right)^{-1}$

As a result:

$-\mathrm{LN}(\mathrm{T})=L N\left(1 /\left(\left(1 / \int_{\alpha}^{\beta}\left(\left(m X^{n}\right) d x\right)\right) *\left(\int_{\mathrm{A}}^{\mathrm{B}}\left(\left(m X^{n}\right) d x\right)\right)\right)\right)^{-1}$

So if the criterion:

$p=1 /\left(\left(1 / \int_{\alpha}^{\beta}\left(\left(m X^{n}\right) d x\right)\right) *\left(\int_{\mathrm{A}}^{\mathrm{B}}\left(\left(m X^{n}\right) d x\right)\right)\right)$

Calculates the possibility of structural parameters, then it not necessary to measure the return period, which is considered as 300 years. Having knowledge about the distribution of temperature programming is considered necessary at natural and agricultural sources. According to the spatial distribution of these characteristics in this study geostatistical methods in the study of zoning and spatial distribution of temperature properties were evaluated in Fars province. With a mean of rainfall data in January, February and March, the seasonal rainfall time series for each station is calculated and then normalized correlation matrix was created between data.

\section{REFERENCES}

[1] Hosseinirad, Abdolmajid. 1382. Reception of Visual Arts (Part I). Printing Company and Iran's School Books.

[2] Ramasht, Mohammad Hussein (2003), Kias theory in geomorphology, Geography and Development Magazine, No. 1, pp. 13-36.

[3] Ramsht Mohammed Hussain. 1385 Adaptive Analysis of Hydrologic Behavior of Corder River Geonrotic Network. Geography and regional development. Fifth number

[4] RasoulJani, Ghorbani, Mohammad Ali, Shamsaee, Abolfazl, Monthly Analysis of Bandar Anzali's Rainfall by Using Theory of Climate Change, Iran Journal of Research, No. 1

[5] Sesquer, H, Hoiar, H. 1382. Temperature changes in the globe in the last century. Third Regional Conference and First National Conference on Climate Change. Isfahan.

[6] Naderi, Ezatollah, 1384. Practical Guide to Providing a Research Plan, Tehran: Badr Publications.

[7] Hashmi Maryam al-Sadat. 1389 Geomorphologic Evidences of Quaternary Climate Change in Fasa City. Master's thesis. Islamic Azad University of Laristan.

[8] Mazidi, Ahmad. Kamaneh, AbdolAli .Mozafari, GholamAli.NarangiFard, Mehdi. Daily rainfall changes based on Ashouee analysis in Shiraz. Geography (Scientific Journal of Iran Geographical Society Journal) Year 14 Issue 50

[9] Ostad-Ali-Askari, K., Shayannejad, M. 2015, Study of sensitivity of Autumnal wheat to under irrigation in Shahrekord, Shahrekord City, Iran. International Journal of Agriculture and Crop Sciences, 8 (4), 602-605.

[10] Shayannejad, M., Akbari, N., Ostad-Ali-Askari, K. 2015, Study of modifications of the river physical specifications on muskingum coefficients, through employment of genetic algorithm. International Journal of Development Research, 5(3), 3782-3785.

[11] Ostad-Ali-Askari, K., Shayannejad, M. 2015, The Reviews of Einstein's Equation of Logarithmic Distribution Platform and the Process of Changes in the Speed Range of the Karkheh River, Khuzestan province, Iran. International Journal of Development Research, 5(3), 3786-3790. 
[12] Ostad-Ali-Askari, K., Shayannejad, M., Ghorbanizadee-Kharazi, H. 2015, Assessment of artificial neural network performance and exponential regression in prediction of effective rainfall, International Journal of Development Research, 5(3),3791-3794.

[13] Shayannejad, M. Akbari, N. and Ostad-Ali-Askari, K. 2015, Determination of the nonlinear Muskingum model coefficients using genetic algorithm and numerical solution of the continuity. Int. J. of Science: Basic and Applied Research, 21(1),1-14.

[14] Ostad-Ali-Askari, K., Shayannejad, M. 2015, The Study of Mixture Design for Foam Bitumen and the Polymeric and Oil Materials Function in Loose Soils Consolidation. Journal of Civil Engineering Research, 5(2), 39-44. DOI: 10.5923/j.jce.20150502.04

[15] Sayedipour, M., Ostad-Ali-Askari, K., Shayannejad, M. 2015, Recovery of Run off of the Sewage Refinery, a Factor for Balancing the Isfahan-Borkhar Plain Water Table in Drought Crisis Situation in Isfahan Province-Iran. American Journal of Environmental Engineering, 5(2): 43-46. DOI: $10.5923 / \mathrm{j}$.ajee.20150502.02

[16] Ostad-Ali-Askari, K., Shayannejad, M. 2015, Developing an Optimal Design Model of Furrow Irrigation Based on the Minimum Cost and Maximum Irrigation Efficiency. International Bulletin of Water Resources \& Development, 3(2), 18-23.

[17] Ostad-Ali-Askari, K., Shayannejad, M. 2015, Presenting a Mathematical Model for Estimating the Deep Percolation Due to Irrigation. International Journal of Hydraulic Engineering, 4(1), 17 21. DOI: 10.5923/j.ijhe.20150401.03.

[18] Ostad-Ali-Askari, K., Shayannejad, M. 2015, Usage of rockfill dams in the HEC-RAS software for the purpose of controlling floods. American Journal of Fluid Dynamics, 5(1), 23-29. DOI: 10.5923/j.ajfd.20150501.03.

[19] Raeisi-Vanani, H., Soltani Todeshki, A. R., Ostad-Ali- Askari, K., Shayannejad, M. 2015, The effect of heterogeneity due to inappropriate tillage on water advance and recession in furrow irrigation. Journal of Agricultural Science, 7(6), 127-136.

[20] Soltani-Todeshki, A. R., Raeisi-Vanani, H., Shayannejad, M., Ostad-Ali-Askari, K. 2015, Effects of magnetized municipal effluent on some chemical properties of soil in furrow irrigation. International Journal of Agriculture and Crop Sciences, 8(3), 482-489.

[21] Ostad-Ali-Askari, K., Shayannejad, M. 2015, Optimal design of pressurized irrigation laterals installed on sloping land. International Journal of Agriculture and Crop Sciences, ISSN 2227670X. 8(5), 792-797.

[22] Ostad-Ali-Askari K, Shayannejad M, Eslamian S, Navab-Pour B. 2016, Comparison of solution of Saint-Venant equations by characteristics and finite difference methods for unsteady flow analysing in open channel. International Journal of Hydrology Science and Technology, 6(3), 918.

[23] Ostad-Ali-Askari K, Shayannejad M, Eslamian S, et al. 2017, Deficit Irrigation: Optimization Models. Management of Drought and Water Scarcity. Handbook of Drought and Water Scarcity, Taylor \& Francis Publisher, USA. Vol. 3. 1th Edition, pp: 373-389.

[24] Eskandari S, Hoodaji M, Tahmourespour A, Abdollahi A, Mohammadian-Baghi T, Eslamian S, Ostad-Ali-Askari K. 2017, Bioremediation of Polycyclic Aromatic Hydrocarbons by Bacillus Licheniformis ATHE9 and Bacillus Mojavensis ATHE13 as Newly Strains Isolated from OilContaminated Soil. Journal of Geography, Environment and Earth Science International, 11(2): $1-11$.

[25] Raeisi Vanani H, Shayannejad M, Soltani Tudeshki A.R, Ostad-Ali-Askari K, Eslamian S, et al. 2017, Development of a new method for determination of infiltration coefficients in furrow irrigation with natural non-uniformity of slope. Sustain. Water Resour. Manag., 3(2): 163-169.

[26] Shojaei N, Shafaei-Bejestan M, Eslamian S, Marani-Barzani M, P. Singh V, Kazemi M, OstadAli-Askari K. 2017, Assessment of Drainage Slope on the Manning Coarseness Coefficient in Mountain Area. International Journal of Constructive Research in Civil Engineering (IJCRCE), 3(1): 33-40.

[27] Bahmanpour H, Awhadi S, Enjili J, Hosseini S.M, Raeisi Vanani H, Eslamian S, Ostad-AliAskari K. 2017, Optimizing Absorbent Bentonite and Evaluation of Contaminants Removal from Petrochemical Industries Wastewater 


\section{AUTHORS' BIOGRAPHY}

Shahide Dehghan, Department of Geography, Najafabad Branch, Islamic Azad University, Najafabad, Iran.

Sayed Abdol Ali Kamaneh, Department of Geography, Shiraz Branch, Islamic Azad University, Shiraz, Iran

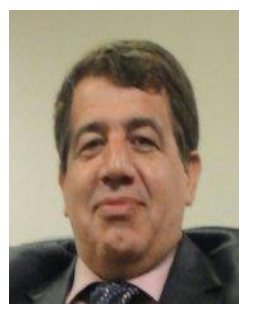

Professor Saeid Eslamian, is a full professor of water system engineering in the Department of Water Engineering at Isfahan University of Technology, Iran, where he has been since 1995. He received his $\mathrm{PhD}$ from Civil and Environmental Engineering School, University of New South Wales, Sydney, Australia, under the supervision of Professor David Pilgrim. His research focuses mainly on water resources planning, management, and sustainability and statistical and environmental hydrology in a changing climate. Formerly, he was a visiting professor at Princeton University, New Jersey, and University of ETH Zurich, Switzerland. On the research side, he started a research partnership in 2014 with McGill University, Montreal, Quebec, Canada. He has contributed to more than 600 publications in journals, books, or as technical reports. He is the founder and chief editor of both the International Journal of Hydrology Science and Technology (Scopus, Inderscience) and the Journal of Flood Engineering. Professor Eslamian is also associate editor of the Journal of Hydrology (Elsevier) and Ecohydrology and Hydrobiology (Elsevier). He has authored more than 150 book chapters and books. Recently, Professor Eslamian published eight handbooks with Taylor \& Francis Group (CRC Press) as chief editor: a three-volume Handbook of Engineering Hydrology (2014), Urban Water Reuse Handbook (2015), a three-volume Handbook of Drought and Water Scarcity (2017), and Underground Aqueducts Handbook (2016).

Amir Gandomkar, Department of Geography, Najafabad Branch, Islamic Azad University, Najafabad, Iran

Maryam Marani-Barzani, Department of Geography, University of Malaya (UM) ,50603 Kuala Lumpur, Malaysia

Mahboubeh Amoushahi-Khouzani, Msc of Water Engineering, Water Engineering Department, Science and Research Branch, Islamic Azad University, Tehran, Iran

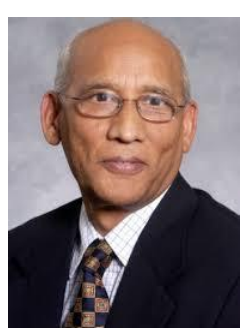

Professor Vijay P. Singh, Full Professor, Department of Biological and Agricultural Engineering \& Zachry Department of Civil Engineering, Texas A and M University, 321 Scoates Hall, 2117 TAMU, College Station, U.S.A.

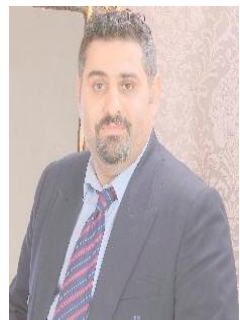

Dr. Kaveh Ostad-Ali-Askari, is a PhD of civil engineering, Department of Water Resources Engineering, Faculty of Civil Engineering. His topics of interest include Groundwater Hydrology, Irrigation and Drainage Engineering, Sustainable Development and Environmental Assessment, Climate and Integrated and Sustainable Water Resource Management, Water System Engineering, Water Resources Planning, Artificial Neural Network, and Genetic Algorithm. He has contributed to more than 124 publications in Journals, Books and Technical Reports. He collaborates as Editorial Board Membership in more than 16 Journals and as reviewers in more than 10 Journals. Currently, he is a Faculty Member of the Department of Civil Engineering, Isfahan (Khorasgan) Branch, Islamic Azad University, Iran

Citation: Dr. Kaveh Ostad-Ali-Askari et al. (2017). Changes in Temperature and Precipitation with the Analysis of Geomorphic Basin Chaos in Shiraz, Iran. International Journal of Constructive Research in Civil Engineering, 3(2), pp.50-57.

Copyright: (C) 2017 Dr. Kaveh Ostad-Ali-Askari, et al. This is an open-access article distributed under the terms of the Creative Commons Attribution License, which permits unrestricted use, distribution, and reproduction in any medium, provided the original author and source are credited 